\title{
Characterization of Physicochemical, Thermal, Structural, and Behavioral Properties of Magnesium Gluconate After Treatment with the Energy of Consciousness
}

\author{
Mahendra Kumar Trivedi $^{1}$, Alice Branton ${ }^{1}$, Dahryn Trivedi ${ }^{1}$, Gopal Nayak ${ }^{1}$, \\ Barry Dean Wellborn ${ }^{1}$, Deborah Lea Smith ${ }^{1}$, Dezi Ann Koster ${ }^{1}$, Elizabeth Patric ${ }^{1}$, \\ Jagdish Singh $^{1}$, Kathleen Starr Vagt ${ }^{1}$, Krista Joanne Callas ${ }^{1}$, Parthasarathi Panda ${ }^{2}$, \\ Kalyan Kumar Sethi ${ }^{2}$, Snehasis Jana ${ }^{2, *}$ \\ ${ }^{1}$ Trivedi Global, Inc., Henderson, Nevada, USA \\ ${ }^{2}$ Trivedi Science Research Laboratory Pvt. Ltd., Bhopal, Madhya Pradesh, India
}

Email address:

publication@trivedieffect.com (S. Jana)

${ }^{*}$ Corresponding author

To cite this article:

Mahendra Kumar Trivedi, Alice Branton, Dahryn Trivedi, Gopal Nayak, Barry Dean Wellborn, Deborah Lea Smith, Dezi Ann Koster, Elizabeth Patric, Jagdish Singh, Kathleen Starr Vagt, Krista Joanne Callas, Parthasarathi Panda, Kalyan Kumar Sethi, Snehasis Jana. Characterization of Physicochemical, Thermal, Structural, and Behavioral Properties of Magnesium Gluconate After Treatment with the Energy of Consciousness. International Journal of Pharmacy and Chemistry. Vol. 3, No. 1, 2017, pp. 1-12.

doi: $10.11648 /$ j.ijpc.20170301.11

Received: February 6, 2017; Accepted: February 21, 2017; Published: March 11, 2017

\begin{abstract}
Magnesium gluconate is a potent antioxidant and widely used for the prevention and treatment of hypomagnesia. The current research was aimed to investigate the impact of The Trivedi Effect ${ }^{\circledR}$ - Energy of Consciousness Healing Treatment on magnesium gluconate for the change in the physicochemical, structural, thermal and behavioral properties using PXRD, PSD, FT-IR, UV-vis spectroscopy, TGA, and DSC analysis. Magnesium gluconate was divided into two parts - one part was control without any Biofield Energy Treatment, while another part was treated with The Trivedi Effect ${ }^{\circledR}$ - Energy of Consciousness Healing Treatment remotely by seven renowned Biofield Energy Healers and defined as The Trivedi Effect ${ }^{\mathbb{B}}$ Treated sample. The PXRD analysis exhibited that the crystallite size of the treated sample was remarkably changed from $24.96 \%$ to $99.98 \%$ compared with the control sample. The average crystallite size was significantly increased by $7.79 \%$ in the treated sample compared with the control sample. PSD analysis revealed that the particle sizes in The Trivedi Effect ${ }^{\circledR}$ Treated sample at $d_{10}, d_{50}$ and $d_{90}$ values were decreased by $5.36 \%, 11.35 \%$ and $0.90 \%$, respectively compared with the control sample. The surface area analysis revealed that surface area of the Biofield Energy Treated sample was significantly increased by 7.48\% compared with the control sample. The FT-IR and UV-vis analysis showed that structure of the magnesium gluconate remained the same in both the treated and control samples. The TGA analysis revealed four steps thermal degradation of both the samples and the total weight loss of Biofield Energy Treated sample was increased by $0.12 \%$ compared with the control sample. The DSC analysis demonstrated that the melting temperature of the Biofield Energy Treated sample $\left(171.29^{\circ} \mathrm{C}\right)$ was increased by $0.18 \%$ compared with the control sample $\left(170.99^{\circ} \mathrm{C}\right)$. The latent heat of fusion was significantly increased by $27.09 \%$ in the treated sample compared with the control sample. The current study revealed that The Trivedi Effect ${ }^{\mathbb{B}}$ - Energy of Consciousness Healing Treatment (Biofield Energy Healing Treatment) might lead to a new polymorphic form of magnesium gluconate, which would be more soluble, bioavailable, and thermally stable compared with the untreated compound. The Biofield Treated sample could be more stable during manufacturing, delivery or storage conditions than the untreated sample. Hence, The Trivedi Effect ${ }^{\mathbb{B}}$ Treated magnesium gluconate would be very useful to design better nutraceutical and/or pharmaceutical formulations that might offer better therapeutic responses against inflammatory diseases, immunological disorders, stress, aging, and other chronic infections.
\end{abstract}

Keywords: Biofield Energy Healing Treatment, Consciousness Energy Healers, The Trivedi Effect ${ }^{\circledR}$, Magnesium Gluconate, PXRD, Particle Size, TGA, DSC 


\section{Introduction}

Magnesium gluconate $\left(\mathrm{MgC}_{12} \mathrm{H}_{22} \mathrm{O}_{14}\right)$ is an organometallic salt of magnesium with gluconic acid and is very useful nutraceutical/pharmaceutical as a source of magnesium [1]. Magnesium is a crucial cofactor of several RNA and DNA processing enzymes and also for those enzymes using AMP, ADP, or ATP as substrates [2]. Magnesium gluconate has been reported as a potent antioxidant agent than other magnesium salts [3]. Magnesium gluconate has shown the highest level of bioavailability than any other magnesium salt and is more physiologically acceptable salt among the magnesium salts such as chloride, sulfate, citrate, lactate, aspartate, etc. [4, 5]. Hence, Magnesium gluconate is recommended as a better salt for magnesium supplementation [6]. Magnesium gluconate has been found to be very useful for the prevention and treatment of several diseases, such as diabetes mellitus, allergies, septic shock, inflammatory diseases, immunological disorders, asthma, arrhythmias, acute myocardial infarction, gestational hypertension, preeclampsia, eclampsia, hearing loss etc. [3, 4, 7-12]. It can be used intravenously in the treatment of ischemia/reperfusion injury due to oxidative stress in order to block free radical flow [13]. This organometallic salt can be used in a skin-tightening cosmetic composition [14]. It is also used as an oral tocolytic agent in women, whose labor is arrested initially with intravenous therapy by acting on nonselective $\beta$-receptor [15]. In this point of view, a novel proprietary herbomineral formulation was designed as a nutraceutical supplement, which can be used for the prevention and treatment of various human disorders. Magnesium gluconate is one of the components in this novel proprietary herbomineral formulation as the source of magnesium.

Since ancient times, many different cultures, religions, and systems of belief have recognized a living force that preserves and inhabits every living organism. This force is the source of 'life' and has been called various names, such as prana by the Hindus, qi or chi by the Chinese, and ki by the Japanese. This is believed to co-relate with the soul, spirit and mind. This hypothetical vital force has been scientifically evaluated and is now considered the Bioenergetics Field. The Biofield Energy is a dynamic electromagnetic field surrounding the human body, resulting from the continuous emission of low-level light, heat, and acoustical energy from the body. Biofield Energy is infinite, paradimensional and can freely flow between the human and environment [19, 20]. Thus, a human has the ability to harness energy from the ionosphere of the earth, the "universal energy field", and transmit it to any living organism(s) or nonliving object(s) around the globe. The object or recipient always receives the energy and responds in a useful way. This process is known as The Trivedi Effect ${ }^{\circledR}$ - Biofield Energy Healing Treatment [21]. Biofield (Putative Energy Field) based Energy Therapies are used worldwide to promote health and healing.
The National Center of Complementary and Integrative Health (NCCIH) has recognized and accepted Biofield Energy Healing as a Complementary and Alternative Medicine (CAM) health care approach in addition to other therapies, medicines and practices such as natural products, deep breathing, yoga, Tai Chi, Qi Gong, chiropractic/osteopathic manipulation, meditation, massage, special diets, homeopathy, progressive relaxation, guided imagery, acupressure, acupuncture, relaxation techniques, hypnotherapy, healing touch, movement therapy, pilates, rolfing structural integration, mindfulness, Ayurvedic medicine, traditional Chinese herbs and medicines, naturopathy, essential oils, aromatherapy, Reiki, cranial sacral therapy and applied prayer (as is common in all religions, like Christianity, Hinduism, Buddhism and Judaism) [22]. Biofield Energy Healing Treatment (The Trivedi Effect $\left.{ }^{(}\right)$has been published in numerous peerreviewed science journals due to its significant impacts in the science fields of biotechnology [23, 24], genetics [25, 26], cancer $[27,28]$, microbiology $[29,30]$, materials science [31, 32], agriculture $[33,34]$, pharmaceuticals $[35,36]$, nutraceuticals $[37,38]$, organic compounds [39, 40]. These publications reported that Biofield Energy Treatment (The Trivedi Effect ${ }^{\mathbb{B}}$ ) has the significant capability to transform the physical, structural, chemical, thermal and behavioral properties of non-living substances as well as modulate the efficacy of various living substance. Although magnesium gluconate displays the highest bioavailability and moderate solubility in water in comparison to other magnesium salts, humans still face problems in achieving their daily requirements of magnesium [41]. The physical and chemical properties such as particle size, crystalline structure, crystallite size, surface area, etc. of a pharmaceutical have a direct influence on the absorption, dissolution, and bioavailability of the drug [42]. The stability of a solid drug with respect to the atmospheric conditions is very important to the pharmaceutical industry during processing, formulation, storage, and packaging in order to achieve better therapeutic efficacy [43]. Biofield Energy Treatment (The Trivedi Effect $\left.{ }^{\circledR}\right)$ has been reported to change the particle size, specific surface area, crystalline, chemical and thermal behavior of an atom/ion through possible mediation of neutrinos [44]. Scientific literature mentions that powder Xray diffraction (PXRD), particle size distribution analysis (PSD), Fourier transform infrared (FT-IR) spectrometry, ultraviolet-visible (UV-vis) spectroscopy, thermogravimetric analysis (TGA), and differential scanning calorimetry (DSC) analysis play an vital role for solving various problems encountered in industries for the pharmaceutical / nutraceutical formulation and developments [45]. By considering these aspects, the physicochemical, structural, thermal, and behavioral properties of the Biofield Energy Treated and untreated magnesium gluconate were studied using various analytical techniques including PXRD, PSD, FT-IR, UV-vis spectroscopy, TGA, and DSC. 


\section{Materials and Methods}

\subsection{Chemicals and Reagents}

Magnesium gluconate hydrate was procured from Tokyo Chemical Industry Co., Ltd. (TCI), Japan. All other chemicals used in the experiment were of analytical grade available in India.

\subsection{Energy of Consciousness Treatment Strategies}

Magnesium gluconate was one of the components of the new proprietary herbomineral formulation, which was developed by our research team and was used per se as the test compound for the current study. The test compound was divided into two parts, one part of the test compound did not receive any sort of treatment and was defined as the untreated or control magnesium gluconate sample. The second part of the test compound was denoted as the Biofield Energy Treated or The Trivedi Effect ${ }^{\mathbb{R}}$ Treated sample. The treated magnesium gluconate was subjected to The Trivedi Effect ${ }^{\circledR}$ Energy of Consciousness Healing Treatment (Biofield Energy Healing Treatment) by the group of seven renowned Biofield Energy Healers remotely. All seven Biofield Energy Healers were remotely located in the U.S.A., while the test compound was located in the research laboratory of GVK Biosciences Pvt. Ltd., Hyderabad, India. The Trivedi Effect ${ }^{\circledR}$ - Energy of Consciousness Healing Treatment (Biofield Energy Healing Treatment) was provided for 5 minutes through the Healer's Unique Energy Transmission process remotely to the test compound, which was kept under laboratory conditions. None of the Biofield Energy Healers in this study visited the laboratory in person, nor had any contact with the compounds. Similarly, the control compound was subjected to "sham" healer for 5 minutes, under the same laboratory conditions. The sham healer did not have any knowledge about the Biofield Energy Treatment. After that, the Biofield Energy Treated and untreated samples were kept in similar sealed conditions and characterized thoroughly by PXRD, PSD, FT-IR, UV-visible spectroscopy, TGA, and DSC analysis.

\subsection{Characterization}

\subsubsection{Powder X-ray Diffraction (PXRD) Analysis}

The PXRD analysis was performed on PANalytical X'pert Pro powder X-ray diffractometer system. The X-ray of wavelength $1.54056 \AA$ was used. The data was collected in the form of a chart of the Bragg angle (20) vs. intensity, and a detailed table containing information on peak intensity counts, d value $(\AA)$, relative intensity (\%), full width half maximum (FWHM) $\left(\theta^{\circ}\right)$. From the XRD results, the crystallite size $(\mathrm{G})$ was calculated using X'pert data collector and X'pert high score plus processing software. The crystallite size $(\mathrm{G})$ was calculated from the Scherrer equation $[46,47]$. The method was based on the width of the diffraction patterns obtained in the X-ray reflected crystalline region. The crystallite size $(\mathrm{G})$ was calculated by using the following equation 1 :

$$
\mathrm{G}=\mathrm{k} \lambda /(\mathrm{b} \operatorname{Cos} \theta)
$$

Where, $\mathrm{k}$ is the equipment constant $(0.5), \lambda$ is the $\mathrm{X}$-ray wavelength $(0.154 \mathrm{~nm})$; $b$ in radians is the full-width at half of the peaks and $\theta$ is the corresponding Bragg angle.

Percent change in crystallite size $(\mathrm{G})$ was calculated using the following equation 2 :

$\%$ change in crystallite size $=\frac{\left[\mathrm{G}_{\text {Treated }}-\mathrm{G}_{\text {Control }}\right]}{\mathrm{G}_{\text {Control }}} \times 100$

Where $\mathrm{G}_{\text {Control }}$ and $\mathrm{G}_{\text {Treated }}$ are the crystallite size of the control and Biofield Energy Treated samples, respectively.

A total of $500.18 \mathrm{mg}$ of the control and Biofield Energy Treated samples individually were used for the analysis and prepared by the back loading technique using the sample preparation kit. The sample was spread on the holder ring in sufficient quantity to fill the ring cavity. It was then pressed down using a powder press block and scrapped the powder that was in surplus using a glass slide in order to get a densely packed specimen. The bottom plate was placed onto the holder ring and clamped in position. The sample holder was then removed from the sample preparation table by turning it upside down. A smooth surface of the sample was obtained to ensure optimum results.

\subsubsection{Particle Size Distribution (PSD) Analysis}

The average particle size and particle size distribution were analyzed using Malvern Mastersizer 2000, UK, with a detection range from $0.01 \mu \mathrm{m}$ to $3000 \mu \mathrm{m}$. The sample unit was filled with dispersant medium and operated the stirrer at $2500 \mathrm{rpm}$. Alignment of the optics was done and taken the background measurement. After the background measurement, the sample was added in to the sample unit with constant monitoring of the obscuration. When the obscuration of the sample reached in between $15 \%$ and $20 \%$, further addition of the sample stopped. When the obscuration was stable, the measurement was taken twice and the average was taken of the two measurements. The average histogram of the two measurements was recorded. The printout of the average histogram of the two measurements were documented in this study. Along with histogram, the data was presented in a table format which includes particle size $(\mu \mathrm{m})$. Also, the values at below $10 \%$ level $\left(\mathrm{d}_{10}\right), 50 \%$ level $\left(\mathrm{d}_{50}\right)$, and $90 \%$ level $\left(\mathrm{d}_{90}\right)$ were calculated from the histogram, and the calculations such as surface area $\left(\mathrm{m}^{2} / \mathrm{g}\right)$ were done by using Mastersizer 2000 software. The percent change in particle size (d) for at below $10 \%$ level $\left(\mathrm{d}_{10}\right), 50 \%$ level $\left(\mathrm{d}_{50}\right)$, and $90 \%$ level $\left(\mathrm{d}_{90}\right)$ was calculated using the following equation 3 :

$$
\% \text { change in particle size }=\frac{\left[\mathrm{d}_{\text {Treated }}-\mathrm{d}_{\text {Control }}\right]}{\mathrm{d}_{\text {Control }}} \times 100
$$

Where, $d_{\text {Control }}$ and $d_{\text {Treated }}$ are the particle size $(\mu \mathrm{m})$ for at below $10 \%$ level $\left(\mathrm{d}_{10}\right), 50 \%$ level $\left(\mathrm{d}_{50}\right)$, and $90 \%$ level $\left(\mathrm{d}_{90}\right)$ of the control and Biofield Energy Treated samples, respectively.

The percent change in surface area (S) was calculated using the following equation 4 : 
$\%$ change in surface area $=\frac{\left[\mathrm{S}_{\text {Treated }}-\mathrm{S}_{\text {Control }}\right]}{\mathrm{S}_{\text {Control }}} \times 100$

Where, $\mathrm{S}_{\text {Control }}$ and $\mathrm{S}_{\text {Treated }}$ are the surface area of the control and Biofield Energy Treated samples, respectively.

\subsubsection{Fourier Transform Infrared (FT-IR) Spectroscopy}

FT-IR spectroscopy of the magnesium gluconate was performed using Spectrum Two (Perkin Elmer, USA) Fourier Transform Infrared Spectrometer with the frequency range of $400-4000 \mathrm{~cm}^{-1}$ by using the pressed $\mathrm{KBr}$ disk technique.

\subsubsection{Ultraviolet-Visible Spectroscopy (UV-Vis) Analysis}

The UV-Vis spectral analysis was carried out using Shimadzu UV-2450 with UV Probe, Japan. The spectrum was recorded using $1 \mathrm{~cm}$ quartz cell with a slit width of 1.0 $\mathrm{nm}$. The wavelength range chosen for recording the spectra was $190-800 \mathrm{~nm}$. The absorbance spectra (in the range of 0.2 to 0.9$)$ and absorbance maximum $\left(\lambda_{\max }\right)$ were recorded.

\subsubsection{Thermal Gravimetric Analysis (TGA)}

The TGA analysis was performed using TGA Q50 (TA Instruments, USA) at a heating rate of $10^{\circ} \mathrm{C} / \mathrm{min}$ from room temperature i.e. $25^{\circ} \mathrm{C}$ to $900^{\circ} \mathrm{C}$ in a nitrogen atmosphere. A total of $15 \mathrm{mg}$ of sample was weighed in a platinum crucible. In TGA, the weight loss for each step was recorded in grams as well as in percent loss with respect to the initial weight. Also, the onset, endset, and peak temperature for each step were recorded in TGA. In DTG, the onset, endset, peak temperature, integral area of the peak and change in heat $(\mathrm{J} / \mathrm{g})$ of each peak were recorded.

Percent change in weight loss (W) was calculated using the following equation 5 :

$\%$ change in weight loss $=\frac{\left[\mathrm{w}_{\text {Treated }}-\mathrm{W}_{\text {Control }}\right]}{\mathrm{w}_{\text {Control }}} \times 100$

Where $\mathrm{W}_{\text {Control }}$ and $\mathrm{W}_{\text {Treated }}$ are the weight loss of the control and Biofield Energy Treated samples, respectively.

\subsubsection{Differential Scanning Calorimetry (DSC)}

Analysis was performed using the DSC Q20 (TA Instruments, USA) Differential Scanning Calorimeter. A total of $8.23 \mathrm{mg}$ of sample was weighed and sealed in an aluminum pan and equilibrated at $25^{\circ} \mathrm{C}$ and heated up to $450^{\circ} \mathrm{C}$ at the heating rate of $10^{\circ} \mathrm{C} / \mathrm{min}$ under nitrogen gas as purge atmosphere with the flow rate of $50 \mathrm{~mL} / \mathrm{min}$. The value for onset, endset, peak temperature, peak height ( $\mathrm{mJ}$ or $\mathrm{mW})$, peak area, and change in heat $(\mathrm{J} / \mathrm{g})$ for each peak were recorded.

The percent change in melting point $(\mathrm{T})$ was calculated using the following equation 6 :

$\%$ change in melting point $=\frac{\left[\mathrm{T}_{\text {Treated }}-\mathrm{T}_{\text {Control }}\right]}{\mathrm{T}_{\text {Control }}} \times 100$

Where, $\mathrm{T}_{\text {Control }}$ and $\mathrm{T}_{\text {Treated }}$ are the melting point of the control and Biofield Energy Treated samples, respectively.

The percent change in the latent heat of fusion $(\Delta \mathrm{H})$ was calculated using the following equation 7 :

$$
\% \text { change in } \Delta \mathrm{H} \text { fusion }=\frac{\left[\Delta \mathrm{H}_{\text {Treated }}-\Delta \mathrm{H}_{\text {Control }}\right]}{\Delta \mathrm{H}_{\text {Control }}} \times 100
$$

Where $\Delta \mathrm{H}_{\text {Control }}$ and $\Delta \mathrm{H}_{\text {Treated }}$ are the latent heat of fusion of the control and Biofield Energy Treated samples, respectively.

\section{Results and Discussion}

\subsection{Powder X-ray Diffraction (PXRD) Analysis}

The PXRD diffractograms of both the control and Biofield Energy Treated magnesium gluconate, as shown in Figure 1, exhibited sharp and intense peaks indicating that both of the samples were crystalline in nature. PXRD data such as the

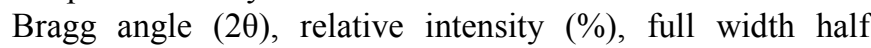
maximum (FWHM) $\left(\theta^{\circ}\right)$, and crystallite size $(G)$ for the control and Biofield Energy Treated magnesium gluconate are presented in Table 1. The crystallite size was calculated using Scherrer equation $[46,47]$. The highest intense peak in both the control and Biofield Energy Treated samples was

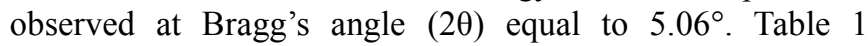
displays the changes of the relative intensities and crystallite size of the Biofield Energy Treated magnesium gluconate compared with the control sample, while their Bragg's angle (20) were almost similar.

The crystallite sizes at position $2 \theta$ equal to nearly $5.1^{\circ}$, $18.5^{\circ}, 19.0^{\circ}, 23.6^{\circ}, 25.5^{\circ}, 27.4^{\circ}, 29.3^{\circ}, 31.4^{\circ}, 34.5^{\circ}, 35.7^{\circ}$, $37.6^{\circ}, 38.9^{\circ}, 39.6^{\circ}$, and $40.4^{\circ}$ (Table 1 , entry $1,6,7,11,13-$ 16 , and $18-23$ ) were significantly increased from $11.09 \%$ to 99.98\% in the Biofield Energy Treated sample compared with the control sample. Consequently, the crystallite sizes of the Biofield Energy Treated sample at $2 \theta$ equal to nearly $9.9^{\circ}, 13.9^{\circ}, 15.8^{\circ}, 18.0^{\circ}, 19.1^{\circ}, 22.4^{\circ}, 24.7^{\circ}, 31.9^{\circ}$, and $49.3^{\circ}$ (Table 1 , entry $2-5,8,10,12,17$, and 26) were significantly decreased from $14.26 \%$ to $24.96 \%$ compared with the control sample.

Table 1. PXRD data for the control and Biofield Energy Treated magnesium gluconate.

\begin{tabular}{|c|c|c|c|c|c|c|c|c|c|}
\hline \multirow{2}{*}{ Entry No. } & \multicolumn{2}{|c|}{ Bragg angle $\left({ }^{\circ} 2 \theta\right)$} & \multicolumn{2}{|c|}{ Relative Intensity (\%) } & \multicolumn{2}{|c|}{ FWHM $\left({ }^{\circ} 2 \theta\right)$} & \multicolumn{3}{|c|}{ Crystallite size (G, nm) } \\
\hline & Control & Treated & Control & Treated & Control & Treated & Control & Treated & \% change \\
\hline 1 & 5.05 & 5.06 & 100.00 & 100.00 & 0.1004 & 0.0836 & 43.88 & 52.70 & 20.10 \\
\hline 2 & 9.89 & 9.88 & 39.51 & 35.25 & 0.0836 & 0.1004 & 52.85 & 44.00 & -16.73 \\
\hline 3 & 13.89 & 13.88 & 44.40 & 45.28 & 0.1004 & 0.1171 & 44.16 & 37.86 & -14.26 \\
\hline 4 & 15.82 & 15.82 & 30.24 & 26.18 & 0.1004 & 0.1338 & 44.26 & 33.21 & -24.96 \\
\hline 5 & 17.92 & 17.99 & 57.74 & 45.76 & 0.1673 & 0.2175 & 26.63 & 20.49 & -23.07 \\
\hline 6 & 18.49 & 18.46 & 88.91 & 83.51 & 0.1338 & 0.1171 & 33.33 & 38.08 & 14.26 \\
\hline 7 & 19.03 & 19.03 & 71.88 & 65.81 & 0.1673 & 0.1506 & 26.68 & 29.64 & 11.09 \\
\hline 8 & 19.15 & 19.14 & 53.76 & 52.24 & 0.0669 & 0.0836 & 66.72 & 53.39 & -19.98 \\
\hline
\end{tabular}




\begin{tabular}{|c|c|c|c|c|c|c|c|c|c|}
\hline \multirow{2}{*}{ Entry No. } & \multicolumn{2}{|c|}{ Bragg angle $\left({ }^{\circ} 2 \theta\right)$} & \multicolumn{2}{|c|}{ Relative Intensity (\%) } & \multicolumn{2}{|c|}{ FWHM $\left({ }^{\circ} 2 \theta\right)$} & \multicolumn{3}{|c|}{ Crystallite size (G, $\mathrm{nm})$} \\
\hline & Control & Treated & Control & Treated & Control & Treated & Control & Treated & $\%$ change $^{*}$ \\
\hline 9 & 20.09 & 20.06 & 23.18 & 21.26 & 0.1171 & 0.1171 & 38.17 & 38.17 & 0.00 \\
\hline 10 & 22.37 & 22.38 & 55.23 & 51.03 & 0.1171 & 0.156 & 38.32 & 28.76 & -24.93 \\
\hline 11 & 23.63 & 23.62 & 55.82 & 52.38 & 0.1338 & 0.1171 & 33.61 & 38.40 & 14.26 \\
\hline 12 & 24.71 & 24.72 & 23.35 & 23.04 & 0.1004 & 0.1171 & 44.88 & 38.48 & -14.26 \\
\hline 13 & 25.46 & 25.50 & 18.90 & 17.51 & 0.1840 & 0.1338 & 24.53 & 33.73 & 37.53 \\
\hline 14 & 27.38 & 27.37 & 42.09 & 39.51 & 0.2175 & 0.1171 & 20.83 & 38.69 & 85.73 \\
\hline 15 & 29.31 & 29.31 & 36.73 & 34.74 & 0.1840 & 0.1004 & 24.73 & 45.32 & 83.27 \\
\hline 16 & 31.42 & 31.41 & 26.88 & 24.02 & 0.1004 & 0.0836 & 45.55 & 54.70 & 20.09 \\
\hline 17 & 31.86 & 31.87 & 23.61 & 22.45 & 0.1338 & 0.1673 & 34.22 & 27.37 & -20.02 \\
\hline 18 & 34.51 & 34.52 & 23.62 & 22.28 & 0.1171 & 0.0836 & 39.37 & 55.14 & 40.08 \\
\hline 19 & 35.70 & 35.72 & 35.27 & 32.66 & 0.1673 & 0.1338 & 27.65 & 34.57 & 25.04 \\
\hline 20 & 37.61 & 37.60 & 27.95 & 25.47 & 0.1338 & 0.1004 & 34.76 & 46.32 & 33.26 \\
\hline 21 & 38.85 & 38.93 & 21.14 & 20.13 & 0.2007 & 0.1506 & 23.26 & 31.01 & 33.30 \\
\hline 22 & 39.64 & 39.61 & 21.18 & 34.05 & 0.3680 & 0.1840 & 12.72 & 25.43 & 99.98 \\
\hline 23 & 40.43 & 40.40 & 40.09 & 39.07 & 0.1506 & 0.1171 & 31.15 & 40.06 & 28.60 \\
\hline 24 & 41.87 & 41.75 & 21.35 & 20.42 & 0.3680 & 0.3680 & 12.81 & 12.81 & -0.04 \\
\hline 25 & 44.12 & 44.14 & 28.49 & 25.62 & 0.1004 & 0.1004 & 47.32 & 47.32 & 0.01 \\
\hline 26 & 49.27 & 49.27 & 15.79 & 14.39 & 0.2007 & 0.2342 & 24.14 & 20.69 & -14.30 \\
\hline \multicolumn{5}{|c|}{ Average crystallite size } & & & 34.48 & 37.17 & 7.79 \\
\hline
\end{tabular}

FWHM: Full width half maximum, "denotes the percentage change in the crystallite size of the Biofield Energy Treated sample with respect to the control sample.
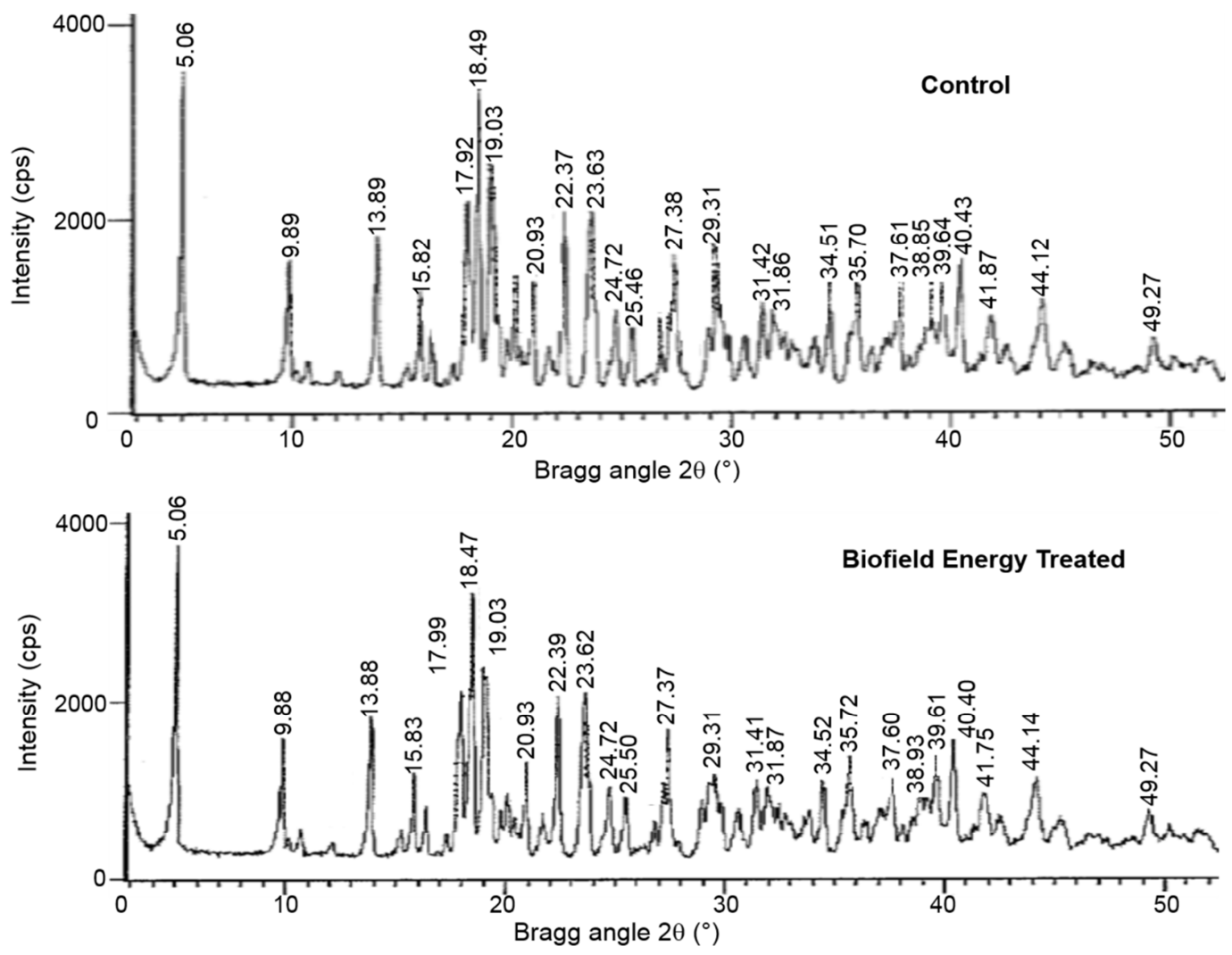

Figure 1. X-ray diffractograms of the control and Biofield Energy Treated magnesium gluconate.

Furthermore, the crystallite sizes of the control and Biofield Energy Treated magnesium gluconate hydrate at $2 \theta$ equal to nearly $20.1^{\circ}, 41.9^{\circ}$, and $44.1^{\circ}$ (Table 1 , entry 9,24 , and 25) remained same. The average particle size of the Biofield Energy Treated sample was significantly increased by $7.79 \%$ compared to the control sample. Scientific literature reported that the changes in the XRD patterns, such as crystallite size and relative intensities, indicated the modification of the morphology of the crystal as well as the proof of polymorphic transition [48-50]. As the crystal morphology of the Biofield Energy Treated sample was altered compared with the control sample, the Biofield Energy Treated sample might be a new polymorphic form of magnesium gluconate. The crystal pattern, size and even polymorphic form of a pharmaceutical play important roles in drug solubility, dissolution and bioavailability. It has been reported in the literature that the alteration in crystal morphology has significant impact on the in vitro dissolution 
rate, which is related with the bioavailability of orally administered pharmaceutical/nutraceutical [43]. So, it can be concluded that the Biofield Energy Healing Treatment might be a very useful method for enhancing the bioavailability of magnesium gluconate.

\subsection{Particle Size Distribution (PSD) Analysis}

The particle sizes at $d_{10}, d_{50}$, and $d_{90}$ values and surface area of both the control and Biofield Energy Treated magnesium gluconate were investigated and the results are presented in Table 2. The control sample showed a particle size values of $d_{10}$ (6.567), $\mathrm{d}_{50}(40.582 \mu \mathrm{m})$, and $\mathrm{d}_{90}(173.282 \mu \mathrm{m})$. After the Biofield Energy Healing Treatment, the particle size values of magnesium gluconate were found to be $6.215,35.976$, and $171.714 \mu \mathrm{m}$ for $\mathrm{d}_{10}, \mathrm{~d}_{50}$, and $\mathrm{d}_{90}$, respectively. Thus, the particle sizes at $\mathrm{d}_{10}, \mathrm{~d}_{50}$ and $\mathrm{d}_{90}$ values of Biofield Energy Treated magnesium gluconate were decreased by $5.36 \%, 11.35 \%$ and $0.90 \%$, respectively compared with the control sample.

Table 2. Particle size data $\left(d_{10}, d_{50}\right.$, and $\left.d_{90}\right)$ and surface area of the control and Biofield Energy Treated magnesium gluconate.

\begin{tabular}{lllll}
\hline Test Item & $\mathbf{d}_{\mathbf{1 0}}(\boldsymbol{\mu m})$ & $\mathbf{d}_{\mathbf{5 0}}(\boldsymbol{\mu m})$ & $\mathbf{d}_{\mathbf{9 0}}(\boldsymbol{\mu m})$ & \\
\hline Control & 6.567 & 40.582 & 173.282 & \\
Biofield Energy Treated & 6.215 & 35.976 & 171.714 & 0.361 \\
Percent change* $(\%)$ & -5.36 & -11.35 & -0.90 & 0.388 \\
\hline
\end{tabular}

*denotes the percentage change in the particle size data $\left(\mathrm{d}_{10}, \mathrm{~d}_{50}\right.$, and $\left.\mathrm{d}_{90}\right)$ and surface area of the Biofield Energy Treated sample with respect to the control sample.

The surface area analysis revealed that the surface area of the Biofield Energy Treated magnesium gluconate $\left(0.361 \mathrm{~m}^{2} / \mathrm{g}\right)$ was significantly increased by $7.48 \%$ from the surface area of the control magnesium gluconate $\left(0.388 \mathrm{~m}^{2} / \mathrm{g}\right)$ as shown in Table 2 .

Poorly crystallized compounds possess more surface area and higher exchange capacities than well-crystallized compounds [51]. In addition, the variation of the crystal morphology in the Biofield Energy Treated sample, which was well-supported from PXRD data, may cause to alter the surface area of the Biofield Energy Treated magnesium gluconate in comparison with the control sample. It has been well established that the particle size, shape and surface area of pharmaceutical compounds have an important impact on solubility, dissolution and in vivo bioavailability, as well as in helping the design of new drug delivery systems [52, 53]. Reducing particle size and higher surface area would enhance the solubility of the solid particles, and consequently would increase the dissolution rate and bioavailability [54]. Thus, it is assumed that the Biofield Energy Treated magnesium gluconate might be dissolved and absorbed at a faster rate and may possibly have more bioavailability than normal magnesium gluconate.
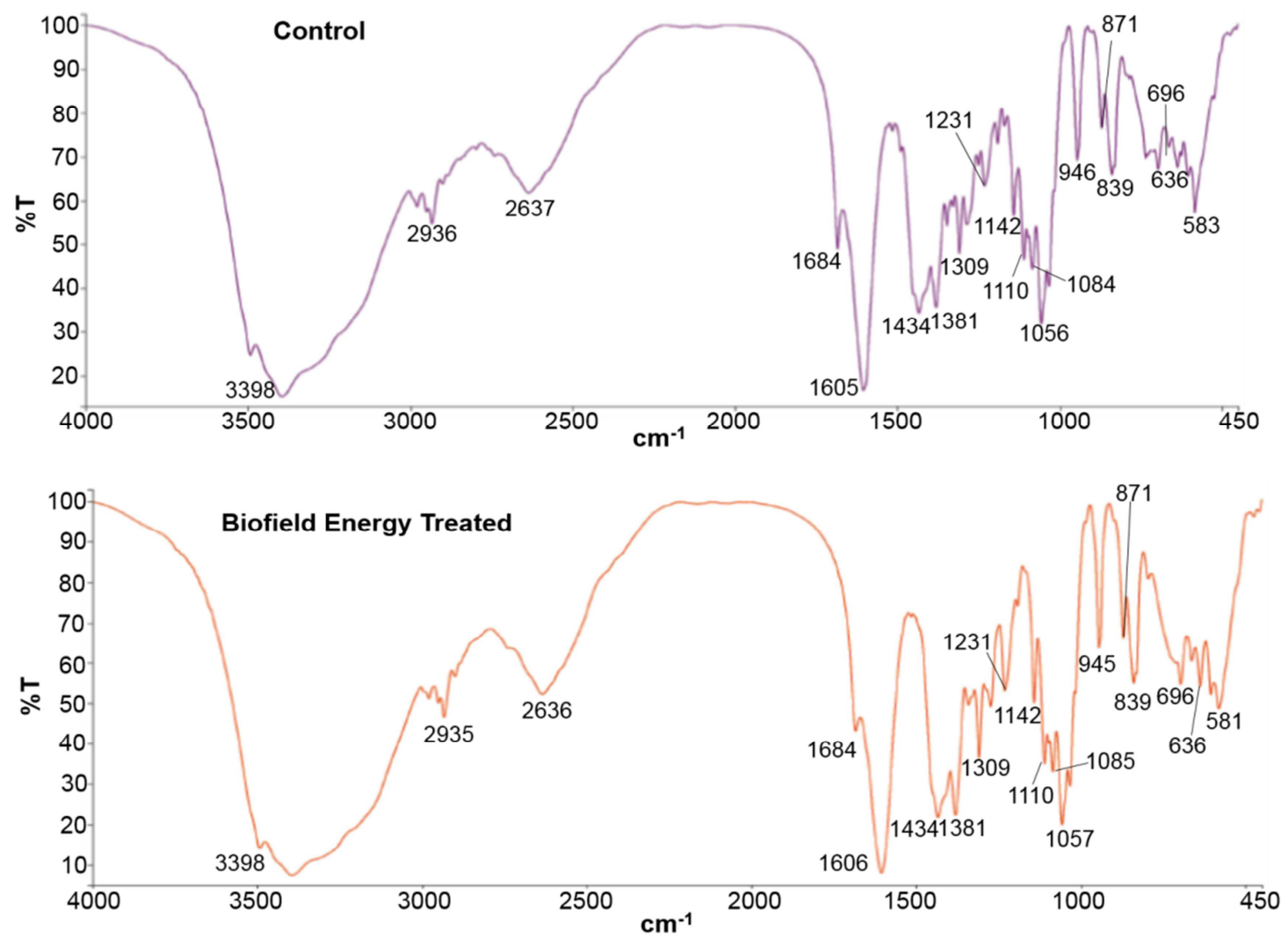

Figure 2. FT-IR spectra of the control and Biofield Energy Treated magnesium gluconate. 


\subsection{Fourier Transform Infrared (FT-IR) Spectroscopy}

The FT-IR spectra of both the control and Biofield Energy Treated magnesium gluconate, as shown in Figure 2, exhibited only one broad band with high intensity at 3398 $\mathrm{cm}^{-1}$, which was attributed to the stretching vibrations of the hydroxyl groups originating from the water present in the magnesium gluconate hydrate. The bands of stretching vibrations of primary and secondary hydroxyl groups from the gluconate part of the compound appeared in this region. These bands were remained invisible due to the intensive broad band of water [55].

The absorption peaks for the deformation vibration of the hydroxyl groups in the plane $\delta(\mathrm{OH})$ and out-of-plane $\gamma(\mathrm{OH})$ indicating the presence of primary and secondary hydroxyl groups were observed at $1434 \mathrm{~cm}^{-1}, 636 \mathrm{~cm}^{-1}$, and $583 \mathrm{~cm}^{-1}$ in the spectrum of the control sample. However, the vibration bands for the of primary and secondary hydroxyl groups were found in the spectra of the Biofield Energy Treated magnesium gluconate at $1434 \mathrm{~cm}^{-1}, 636 \mathrm{~cm}^{-1}$, and $581 \mathrm{~cm}^{-1}$. The FT-IR spectra of the control sample displayed $\mathrm{C}-\mathrm{H}$ stretching at $2936 \mathrm{~cm}^{-1}$ and $1381 \mathrm{~cm}^{-1}$, while these peaks were observed in the Biofield Energy Treated sample at 2935 $\mathrm{cm}^{-1}$ and $1381 \mathrm{~cm}^{-1}$. A very sharp and intensive band at 1605 $\mathrm{cm}^{-1}$ for $\mathrm{C}=\mathrm{O}$ stretching vibration of a carbonyl group of carboxylate anion was observed in the spectrum of the control sample, while this vibration band was found in the spectrum of the Biofield Energy Treated magnesium gluconate at $1606 \mathrm{~cm}^{-1}$. The band of the $\mathrm{C}-\mathrm{O}$ stretching vibrations of the primary alcohol group was observed in the spectra of the control and Biofield Energy Treated samples at $1056 \mathrm{~cm}^{-1}$ and $1057 \mathrm{~cm}^{-1}$, respectively. The absorption peaks at $1231 \mathrm{~cm}^{-1}$ and $1142 \mathrm{~cm}^{-1}$ due to the $\mathrm{C}-\mathrm{O}$ stretching vibrations of the secondary alcohol groups were observed in the spectra of both the control and Biofield Energy Treated samples. The FT-IR analysis indicated that there was no significant alteration of the characteristic peaks for the functional groups. Hence, it can be concluded that the structure of the magnesium gluconate remained the same in both the Biofield Energy Treated and control samples.

\subsection{Ultra Violet-Visible Spectroscopy (UV-Vis) Analysis}

Literature reported that $0.1 \%$ aqueous solution of magnesium gluconate showed a maximum absorption peak $\left(\lambda_{\max }\right)$ at $194.7 \mathrm{~nm}$ [56]. The UV-vis spectra of both the control and Biofield Energy Treated samples (Figure 3) showed that the wavelength for the maximum absorbance $\left(\lambda_{\max }\right)$ of both the control and Biofield Energy Treated samples were at $198.8 \mathrm{~nm}$ with a minor shift of absorbance maxima from 2.3126 (control sample) to 2.3154 (Biofield Energy Treated sample).
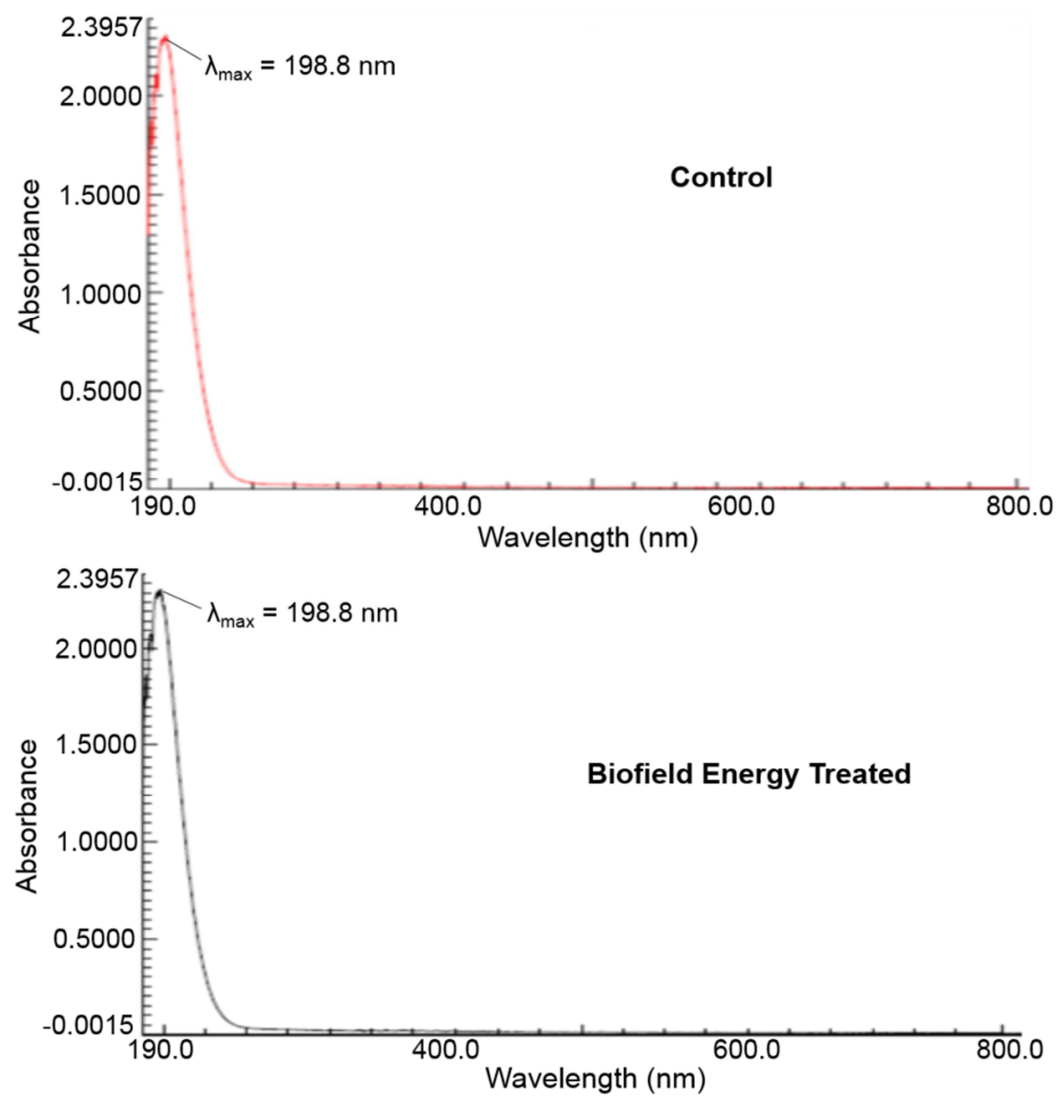

Figure 3. UV-Vis spectra of the control and Biofield Energy Treated magnesium gluconate. 
The UV absorbance happens due to the different types of energy transitions from the singlet to the singlet excited state such as $\sigma \rightarrow \sigma^{*}, \mathrm{n} \rightarrow \pi^{*}$, and $\pi \rightarrow \pi^{*}$. These types of electronic transitions are happened when the difference in energy between the lowest unoccupied molecular orbital (LUMO) and the highest occupied molecular orbital (HOMO) is significantly higher than the activation energy of the compound [57]. As there was no significant change in the $\lambda_{\max }$ of the Biofield Energy Treated sample compared with the control, it is inferred that the structural configuration or activation energy of the Biofield Energy Treated sample was not different from the control sample.

\subsection{Thermal Gravimetric Analysis (TGA)}

The TGA and DSC are very useful techniques for the comparison of the thermal stabilities of pharmaceutical solids, determination of several kinetic parameters, and accomplishment of drug/excipient compatibility data for the pre-formulation study [58]. The TGA study of both the control and the Biofield Energy Treated magnesium gluconate (Figure 4) exhibited four thermal degradation steps and the data are presented in Table 3.

Table 3. Thermal degradation steps of the control and Biofield Energy Treated magnesium gluconate.

\begin{tabular}{|c|c|c|c|c|c|}
\hline \multirow{2}{*}{ S. No. } & \multicolumn{2}{|c|}{ Temperature $\left({ }^{\circ} \mathrm{C}\right)$} & \multicolumn{2}{|c|}{$\%$ Weight loss } & \multirow[t]{2}{*}{$\%$ Change } \\
\hline & Control & Biofield Energy Treated & Control & Biofield Energy Treated & \\
\hline $1^{\text {st }}$ step of degradation & 75.49 & 73.00 & 1.11 & 1.09 & -1.80 \\
\hline $2^{\text {nd }}$ step of degradation & 188.00 & 187.37 & 8.76 & 8.62 & -1.60 \\
\hline 4th step of degradation & 600.84 & 597.63 & 21.40 & 21.30 & -0.47 \\
\hline Total weight loss & - & - & 69.43 & 69.51 & 0.12 \\
\hline
\end{tabular}

*denotes the percentage change in the weight loss of the Biofield Energy Treated sample with respect to the control sample.

The weight losses of the Biofield Energy Treated sample at the first, second, and fourth steps of thermal degradation were reduced by $1.80 \%, 1.60 \%$ and $0.47 \%$, respectively compared with the control sample. Consequently, the weight loss of the Biofield Energy Treated magnesium gluconate at the third step degradation was increased by $0.89 \%$ compared with the control sample. The first step degradation was probably associated with the removal of water of both the samples.
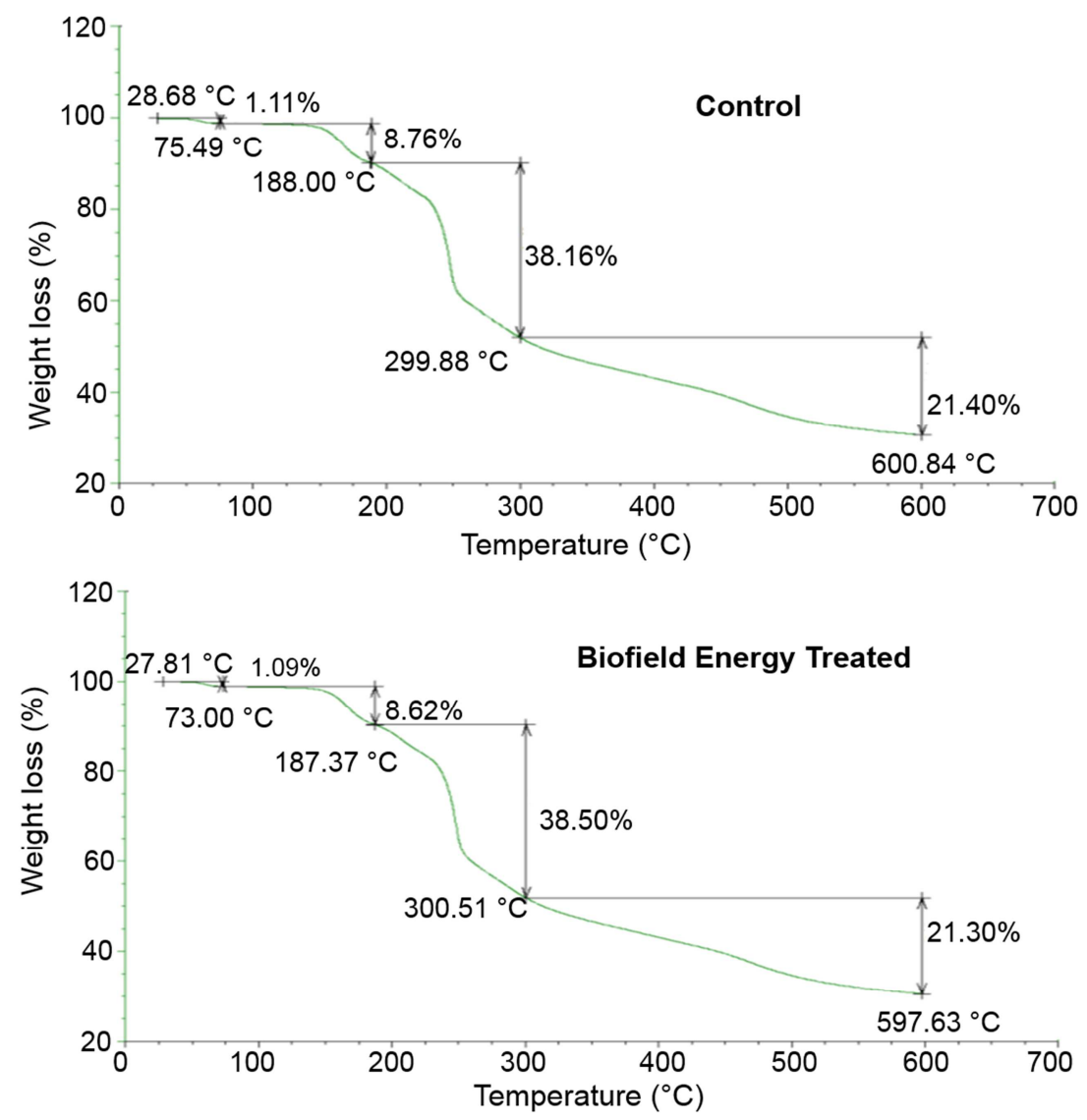

Figure 4. TGA thermograms of both the control and Biofield Energy Treated magnesium gluconate. 
The total weight loss was $69.43 \%$ and $69.51 \%$ in the control and Biofield Energy Treated samples, respectively from their initial weight from room temperature to $600^{\circ} \mathrm{C}$ (Table 3). Thus, the total weight loss of the Biofield Energy Treated sample was increased by $0.12 \%$ compared with the control sample.

\subsection{Differential Scanning Calorimetry (DSC) Analysis}

The DSC thermograms of both the control and Biofield Energy Treated magnesium gluconate (Figure 5) and showed two endothermic peaks. Their DSC data are presented in Table 4. The first broaden endothermic (minor) peak was due to the water removal from the sample. The second sharp endothermic (major) peak was due to the melting temperature of the magnesium gluconate.

The DSC data analysis (Table 4) revealed that the melting temperature of the Biofield Energy Treated sample $\left(171.29^{\circ} \mathrm{C}\right)$ was increased by $0.18 \%$ compared with the control sample $\left(170.99^{\circ} \mathrm{C}\right)$. The control and Biofield Energy Treated samples of magnesium gluconate exhibited a latent heat of fusion of $346.70 \mathrm{~J} / \mathrm{g}$ and $272.80 \mathrm{~J} / \mathrm{g}$, respectively. The latent heat of fusion in the Biofield Energy Treated magnesium gluconate was significantly increased by $27.09 \%$ compared with the control sample (Table 4).
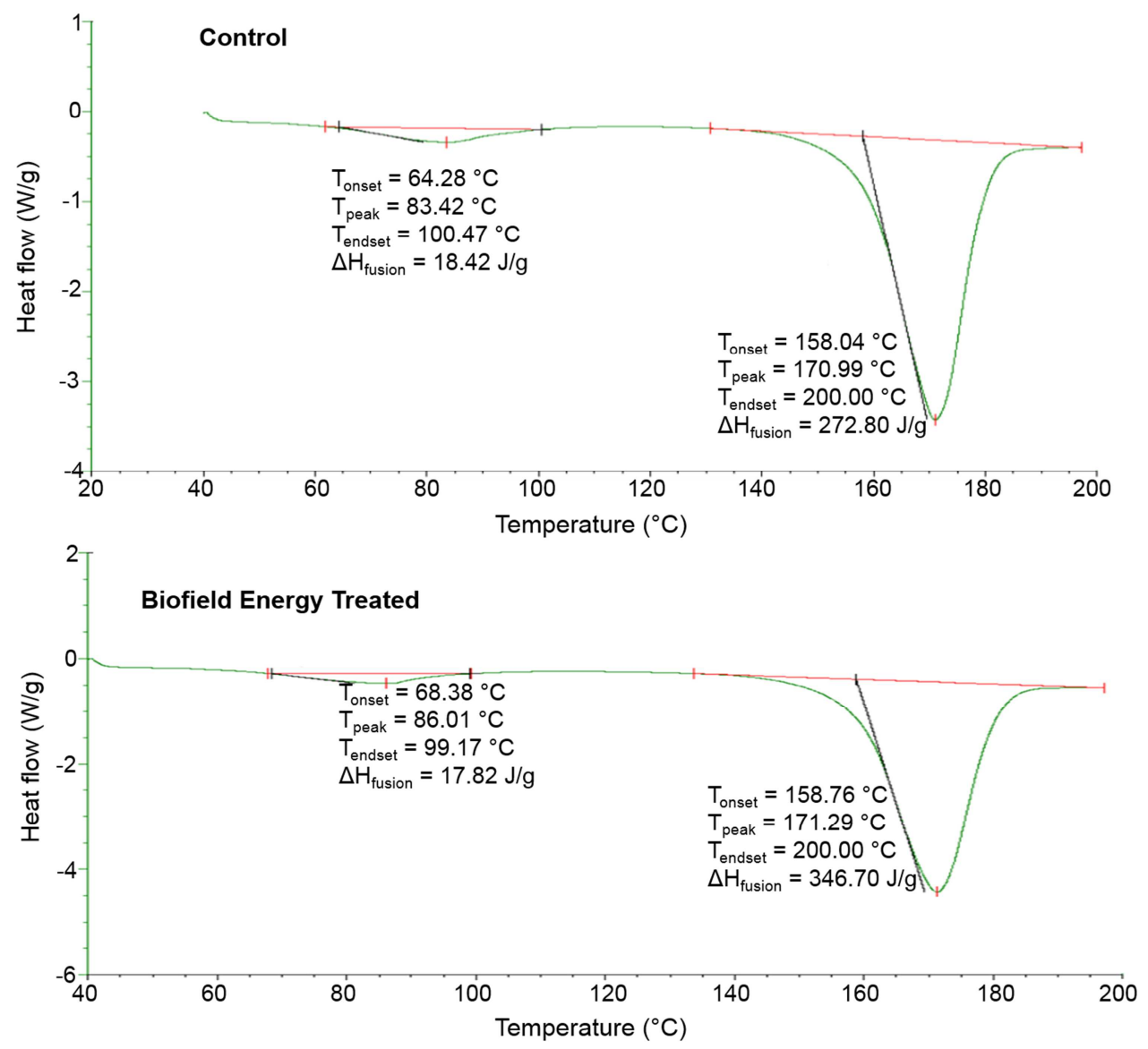

Figure 5. DSC thermograms of the control and Biofield Energy Treated magnesium gluconate.

Table 4. The latent heat of fusion $(J / G)$ and melting point $\left({ }^{\circ} \mathrm{C}\right)$ values of the control and Biofield Energy Treated magnesium gluconate.

\begin{tabular}{lllll}
\hline Endothermic peak & Description & $\mathbf{T}_{\text {onset }}\left({ }^{\circ} \mathbf{C}\right)$ & $\mathbf{T}_{\text {peak }}\left({ }^{\circ} \mathbf{C}\right)$ & $\mathbf{T}_{\text {endset }}\left({ }^{\circ} \mathbf{C}\right)$ \\
\hline \multirow{3}{*}{ Minor peak } & Control sample & 64.28 & 83.42 & 100.47 \\
& Biofield Energy Treated sample & 68.38 & 86.01 & 99.17 \\
& \% Change & 6.38 & 3.10 & 18.42 \\
Major peak & Control sample & 158.04 & 170.99 & -1.29 \\
& Biofield Energy Treated sample & 158.76 & 171.29 & 200.00 \\
& \% Change & 0.46 & 0.18 & 200.00 \\
\hline
\end{tabular}

$\mathrm{T}_{\text {onset }}$ : Onset melting temperature, $\mathrm{T}_{\text {peak }}$ : Peak melting temperature, $\mathrm{T}_{\text {endset: }}$ Endset melting temperature, $\Delta \mathrm{H}$ : Latent heat of fusion, ${ }^{*}$ denotes the percentage change of the Biofield Energy Treated sample with respect to the control sample.

Additionally, the temperature for water removal from the Biofield Energy Treated sample was increased by $3.10 \%$ with a $3.26 \%$ decreased $\Delta \mathrm{H}_{\text {fusion }}$ compared with the control sample. The analysis indicated that the thermal stability of the Biofield Energy Treated sample was significantly improved compared with the control sample. 


\section{Conclusions}

The current analysis anticipated the significant impact of The Trivedi Effect ${ }^{\circledR}$ - Energy of Consciousness Healing Treatment (Biofield Energy Healing Treatment) on physicochemical, thermal and behavioral properties of magnesium gluconate. The PXRD analysis showed that the crystallite size of The Trivedi Effect ${ }^{\mathbb{B}}$ Treated magnesium gluconate was significantly altered from $-24.96 \%$ to $99.98 \%$ compared with the control sample. The average crystallite size of the Biofield Energy Treated sample was significantly increased by $7.79 \%$ compared with the control sample. Overall, the PXRD analysis exposed that the crystal morphology of the Biofield Energy Treated sample was significantly changed compared with the control sample. PSD analysis revealed that the particle sizes at $\mathrm{d}_{10}, \mathrm{~d}_{50}$ and $\mathrm{d}_{90}$ values were decreased by $5.36 \%, 11.35 \%$ and $0.90 \%$, respectively in The Trivedi Effect ${ }^{\mathbb{B}}$ Treated sample compared with the control sample. Consequently, the surface area of the Biofield Energy Treated sample was significantly increased by $7.48 \%$ compared with the control sample. The TGA analysis showed four steps thermal degradation of both the samples and the total weight loss was increased by $0.12 \%$ in the Biofield Energy Treated sample compared with the control sample. The DSC analysis demonstrated that the melting temperature of the Biofield Energy Treated sample $\left(171.29^{\circ} \mathrm{C}\right)$ was increased by $0.18 \%$ with a significant $(27.09 \%)$ enhancement in the latent heat of fusion compared with the control sample $\left(170.99^{\circ} \mathrm{C}\right)$. This finding revealed that the thermal stability of the Biofield Energy Treated sample was significantly improved compared with the control sample. Thus, The Trivedi Effect ${ }^{\mathbb{B}}$ Treated magnesium gluconate would be a new polymorphic form of magnesium gluconate, which would be more soluble, bioavailable, and thermally stable compared with the untreated compound. The Biofield Energy Treated sample could be more stable during manufacturing, delivery or storage conditions than the untreated sample. Briefly, The Trivedi Effect ${ }^{\circledR}$ - Energy of Consciousness Healing Treatment (Biofield Energy Healing Treatment) could be a useful approach in the design of better nutraceutical and/or pharmaceutical formulations that can offer significant therapeutic responses against various diseases such as diabetes mellitus, allergies and septic shock; stress-related disorders like sleep disorder, insomnia, anxiety, depression, Attention Deficit Disorder (ADD), Attention Deficit Hyperactive Disorder (ADHD), mental restlessness (mind chattering), brain frog, low libido, impotency, lack of motivation, mood swings, fear of the future, confusion, migraines, headaches, forgetfulness, overwhelm, loneliness, worthlessness, indecisiveness, frustration, irritability, chronic fatigue, obsessive/compulsive behavior and panic attacks; inflammatory diseases and immunological disorders like Lupus, Systemic Lupus Erythematosus, Hashimoto Thyroiditis, Type 1 Diabetes, Asthma, Chronic peptic ulcers, Tuberculosis, Hepatitis, Chronic active hepatitis, Celiac Disease (gluten-sensitive enteropathy), Addison Disease,
Crohn's disease, Graves' Disease, Pernicious and Aplastic Anemia, Sjogren Syndrome, Irritable Bowel Syndrome (IBS), Multiple Sclerosis, Rheumatoid arthritis, Chronic periodontitis, Ulcerative colitis, Chronic sinusitis, Myasthenia Gravis, Atherosclerosis, Vasculitis, Dermatitis, Diverticulitis, Rheumatoid Arthritis, Reactive Arthritis, Alopecia Areata, Psoriasis, Scleroderma, Fibromyalgia, Chronic Fatigue Syndrome and Vitiligo; aging-related diseases like cardiovascular disease, arthritis, cancer, Alzheimer's disease, dementia, cataracts, osteoporosis, diabetes, hypertension, glaucoma, hearing loss, Parkinson's Disease, Huntington's Disease, Prion Disease, Motor Neurone Disease, Spinocerebellar Ataxia, Spinal muscular atrophy, Amyotrophic lateral sclerosis, Friedreich's Ataxia and Lewy Body Disease, chronic infections and much more.

\section{Abbreviations}

DSC: Differential scanning calorimetry, FT-IR: Fourier transform infrared spectroscopy, FWHM: Full width half maximum, G: Crystallite size, HOMO: Highest energy occupied molecular orbital, LUMO: Lowest energy unoccupied molecular orbital, TGA: Thermal gravimetric analysis, $\mathrm{T}_{\text {onset }}$ : Onset melting temperature, $\mathrm{T}_{\text {peak }}$ : Peak melting temperature, $\mathrm{T}_{\text {endset }}$ : Endset melting temperature, $\Delta \mathrm{H}$ : Latent heat of fusion, UV-vis: Ultraviolet-visible spectroscopy, PSD: Particle size distribution; PXRD: Powder $\mathrm{X}$-ray diffraction.

\section{Acknowledgements}

The authors are grateful to GVK Biosciences Pvt. Ltd., Trivedi Science, Trivedi Global, Inc., and Trivedi Master Wellness for their assistance and support during this work.

\section{References}

[1] Ramachandran S, Fontanille P, Pandey A, Larroche C (2006) Gluconic acid: Properties, applications and microbial production. Food Technol Biotechnol 44: 185-195.

[2] Frick DN, Banik S, Rypma RS (2007) Role of divalent metal cations in ATP hydrolysis catalyzed by the hepatitis $\mathrm{C}$ virus NS3 helicase: Magnesium provides a bridge for ATP to fuel unwinding. J Mol Biol 365: 1017-1032.

[3] Fleming TE, Mansmann Jr HC (1999) Methods and compositions for the prevention and treatment of diabetes mellitus. United States Patent 5871769, 1-10.

[4] Fleming TE, Mansmann Jr HC (1999) Methods and compositions for the prevention and treatment of immunological disorders, inflammatory diseases and infections. United States Patent 5939394, 1-11.

[5] Coudray C, Rambeau M, Feillet-Coudray C, Gueux E, Tressol JC, Mazur A, Rayssiguier Y (2005) Study of magnesium bioavailability from ten organic and inorganic $\mathrm{Mg}$ salts in $\mathrm{Mg}$ depleted rats using a stable isotope approach. Magnes Res 18: 215-223. 
[6] White J, Massey L, Gales SK, Dittus K, Campbell K (1992) Blood and urinary magnesium kinetics after oral magnesium supplements. Clin Ther 14: 678-687.

[7] Guerrera MP, Volpe SL, Mao JJ (2009) Therapeutic uses of magnesium. Am Fam Physician 80: 157-162.

[8] Gums JG (2004) Magnesium in cardiovascular and other disorders. Am J Health Syst Pharm 61: 1569-1576.

[9] Gröber U, Schmidt J, Kisters K (2015) Magnesium in prevention and therapy. Nutrients 7: 8199-8226.

[10] Sales CH, Pedrosa Lde F (2006) Magnesium and diabetes mellitus: Their relation. Clin Nutr 25: 554-562.

[11] Nageris BI, Ulanovski D, Attias J (2004) Magnesium treatment for sudden hearing loss. Ann Otol Rhinol Laryngol 113: $672-675$

[12] Lysakowski C, Dumont L, Czarnetzki C, Tramer MR (2007) Magnesium as an adjuvant to postoperative analgesia: A systematic review of randomized trials. Anesth Analg 104: 1532-1539.

[13] Weglicki WB (2000) Intravenous magnesium gluconate for treatment of conditions caused by excessive oxidative stress due to free radical distribution. United States Patent 6100297, $1-6$.

[14] Lee KH, Chung SH, Song JH, Yoon JS, Lee J, Jung MJ, Kim JH (2013) Cosmetic compositions for skin-tightening and method of skin-tightening using the same. United States Patent 8580741 B2.

[15] Martin RW, Martin JN Jr, Pryor JA, Gaddy DK, Wiser WL, Morrison JC (1988) Comparison of oral ritodrine and magnesium gluconate for ambulatory tocolysis. Am J Obstet Gynecol 158: 1440-1445.

[16] Jahnen-Dechent W, Ketteler M (2012) Magnesium basics. Clin Kidney J 5: i3-i14.

[17] Fine KD, Santa Ana CA, Porter JL, Fordtran JS (1991) Intestinal absorption of magnesium from food and supplements. J Clin Invest 88: 396-402.

[18] Stenger VJ (1999) Bioenergetic Fields. Sci Rev Alternative Med 3.

[19] Rogers, M (1989) "Nursing: A Science of Unitary Human Beings." In J. P. Riehl-Sisca (ed.) Conceptual Models for Nursing Practice. $3^{\text {rd }}$ edition. Norwark: Appleton \& Lange.

[20] Hammerschlag R, Jain S, Baldwin AL, Gronowicz G, Lutgendorf SK, Oschman JL, Yount GL (2012) Biofield research: A roundtable discussion of scientific and methodological issues. J Altern Complement Med 18: 10811086 .

[21] Koithan M (2009) Introducing complementary and alternative therapies. J Nurse Pract 5: 18-20.

[22] Trivedi MK, Branton A, Trivedi D, Nayak G, Bairwa K, Jana S (2015) Physical, thermal, and spectroscopic characterization of biofield energy treated murashige and skoog plant cell culture media. Cell Biology 3: 50-57.

[23] Trivedi MK, Branton A, Trivedi D, Nayak G, Bairwa K, Jana S (2015) Physical, thermal, and spectroscopic characterization of biofield energy treated potato micropropagation medium. American Journal of Bioscience and Bioengineering 3: 106-113.
[24] Trivedi MK, Branton A, Trivedi D, Shettigar H, Nayak G, Mondal SC, Jana S (2015) Phenotyping and genotyping characterization of Proteus vulgaris after biofield treatment. International Journal of Genetics and Genomics 3: $66-73$.

[25] Trivedi MK, Branton A, Trivedi D, Gangwar M, Jana S (2015) Antimicrobial susceptibility, biochemical characterization and molecular typing of biofield treated Klebsiella pneumoniae. J Health Med Inform 6: 206.

[26] Trivedi MK, Patil S, Shettigar H, Mondal SC, Jana S (2015) The potential impact of biofield treatment on human brain tumor cells: A time-lapse video microscopy. J Integr Oncol 4: 141.

[27] Trivedi MK, Patil S, Shettigar H, Gangwar M, Jana S (2015) In vitro evaluation of biofield treatment on cancer biomarkers involved in endometrial and prostate cancer cell lines. J Cancer Sci Ther 7: 253-257.

[28] Trivedi MK, Branton A, Trivedi D, Nayak G, Gangwar M, Jana S (2015) Improved susceptibility pattern of antimicrobials using vital energy treatment on Shigella sonnei. American Journal of Internal Medicine 3: 231-237.

[29] Trivedi MK, Branton A, Trivedi D, Nayak G, Shettigar H, Mondal SC, Jana S (2015) Effect of biofield energy treatment on Streptococcus group B: A postpartum pathogen. J Microb Biochem Technol 7: 269-273.

[30] Trivedi MK, Nayak G, Patil S, Tallapragada RM, Latiyal O (2015) Impact of biofield treatment on physical, structural and spectral properties of antimony sulfide. Ind Eng Manage 4: 165.

[31] Trivedi MK, Nayak G, Patil S, Tallapragada RM, Latiyal O (2015) Studies of the atomic and crystalline characteristics of ceramic oxide nano powders after bio field treatment. Ind Eng Manage 4: 161.

[32] Nayak G, Altekar N (2015) Effect of a biofield treatment on plant growth and adaptation. J Environ Health Sci 1: 1-9.

[33] Trivedi MK, Branton A, Trivedi D, Nayak G, Mondal SC, Jana S (2015) Evaluation of plant growth, yield and yield attributes of biofield energy treated mustard (Brassica juncea) and chick pea (Cicer arietinum) seeds. Agriculture, Forestry and Fisheries 4: 291-295.

[34] Trivedi MK, Branton A, Trivedi D, Shettigar H, Bairwa K, Jana S (2015) Fourier transform infrared and ultravioletvisible spectroscopic characterization of biofield treated salicylic acid and sparfloxacin. Nat Prod Chem Res 3: 186.

[35] Trivedi MK, Patil S, Shettigar H, Bairwa K, Jana S (2015) Effect of biofield treatment on spectral properties of paracetamol and piroxicam. Chem Sci J 6: 98.

[36] Trivedi MK, Nayak G, Patil S, Tallapragada RM, Jana S, Mishra RK (2015) Bio-field treatment: An effective strategy to improve the quality of beef extract and meat infusion powder. J Nutr Food Sci 5: 389.

[37] Trivedi MK, Tallapragada RM, Branton A, Trivedi D, Nayak G, Latiyal O, Jana S (2015) Evaluation of biofield energy treatment on physical and thermal characteristics of selenium powder. Journal of Food and Nutrition Sciences. 3: 223-228.

[38] Trivedi MK, Tallapragada RM, Branton A, Trivedi D, Nayak G, Mishra RK, Jana S (2015) Characterization of physical, spectral and thermal properties of biofield treated 1,2,4triazole. J Mol Pharm Org Process Res 3: 1. 
[39] Trivedi MK, Branton A, Trivedi D, Nayak G, Mishra RK, Jana S (2015) Characterization of physical, thermal and spectral properties of biofield treated 2-aminopyridine. Science Journal of Analytical Chemistry 3: 127-134.

[40] Ranade VV, Somberg JC (2001) Bioavailability and pharmacokinetics of magnesium after administration of magnesium salts to humans. Am J Ther 8: 345-357.

[41] Chereson R (2009) Bioavailability, bioequivalence, and drug selection. In: Makoid CM, Vuchetich PJ, Banakar UV (eds) Basic pharmacokinetics ( ${ }^{\text {st }}$ Edn) Pharmaceutical Press, London.

[42] Blagden N, de Matas M, Gavan PT, York P (2007) Crystal engineering of active pharmaceutical ingredients to improve solubility and dissolution rates. Adv Drug Deliv Rev 59: 617630 .

[43] Trivedi MK, Mohan TRR (2016) Biofield energy signals, energy transmission and neutrinos. American Journal of Modern Physics 5: 172-176.

[44] Chauhan A, Chauhan P (2014) Powder XRD technique and its applications in science and technology. J Anal Bioanal Tech 5: 212.

[45] Alexander L, Klug HP (1950) Determination of crystallite size with the X-Ray spectrometer. J App Phys 21: 137.

[46] Langford JI, Wilson AJC (1978) Scherrer after sixty years: A survey and some new results in the determination of crystallite size. J Appl Cryst 11: 102-113.

[47] Inoue M, Hirasawa I (2013) The relationship between crystal morphology and XRD peak intensity on $\mathrm{CaSO}_{4} \cdot 2 \mathrm{H}_{2} \mathrm{O}$. J Crystal Growth 380: 169-175.

[48] Raza K, Kumar P, Ratan S, Malik R, Arora S (2014) Polymorphism: The phenomenon affecting the performance of drugs. SOJ Pharm Pharm Sci 1: 10.
[49] Brittain HG (2009) Polymorphism in pharmaceutical solids in Drugs and Pharmaceutical Sciences, volume 192, $2^{\text {nd }}$ Edn, Informa Healthcare USA, Inc., New York.

[50] Kale VV, Gadekar S, Ittadwar AM (2011) Particle size enlargement: Making and understanding of the behavior of powder (particle) system. Syst Rev Pharm 2: 79.

[51] Murray HH, Lyons SC (1960) Further correlation of kaolinite crystallinity with chemical and physical properties. Clays Clay Miner 8: 11-17.

[52] Sun J, Wang F, Sui Y, She Z, Zhai W, Wang C, Deng Y (2012) Effect of particle size on solubility, dissolution rate, and oral bioavailability: Evaluation using coenzyme $\mathrm{Q}_{10}$ as naked nanocrystals. Int J Nanomed 7: 5733-5744.

[53] Khadka P, Ro J, Kim H, Kim I, Kim JT, Kim H, Cho JM, Yun G, Lee J (2014) Pharmaceutical particle technologies: An approach to improve drug solubility, dissolution and bioavailability. Asian J Pharm Sci 9: 304-316.

[54] Buckton G, Beezer AE (1992) The relationship between particle size and solubility. Int J Pharmaceutics 82: R7-R10.

[55] Nikolic VD, Illic DP, Nikolic LB, Stanojevic LP, Cakic MD, Tacic AD, Ilic-Stojanovic SS (2014) The synthesis and characterization of iron (II) gluconate. Advanced Technologies 3: 16-24.

[56] Ji L, Yin W, Fu-Jia M (2004) Confirmation of the chemical structure of magnesium gluconate. Pharmaceutical Care and Research 4: 272-273.

[57] Hesse M, Meier H, Zeeh B (1997) Spectroscopic methods in organic chemistry, Georg Thieme Verlag Stuttgart, New York.

[58] Alves R, Reis TVS, Silva LCC, Storpírtis S, Mercuri LP, Matos JR (2010) Thermal behavior and decomposition kinetics of rifampicin polymorphs under isothermal and nonisothermal conditions. Braz J Pharm Sci 46: 343-351. 